\title{
Mechanical Engineering Program Assessment in the Schaefer School of Engineering at Stevens Institute of Technology
}

\author{
Hamid Hadim, Kishore Pochiraju, Costas Chassapis, \\ David Vaccari, Keith Sheppard, George Korfiatis \\ Charles V. Schaefer, Jr. School of Engineering \\ Stevens Institute of Technology \\ Hoboken, New Jersey
}

\begin{abstract}
The Charles V. Schaefer, Jr. School of Engineering at Stevens Institute of Technology has recently completed successfully its first ABET visit based on EC2000 criteria. The assessment system developed for the Mechanical Engineering Program within the School are presented with emphasis on the outcomes assessment strategy developed and samples of the assessment instruments/tools that were designed. These include course-level assessment of student performance, program-level assessment tools and assessment at the School of Engineering level. In particular, an innovative technique for direct assessment at the course level is developed to demonstrate achievement of course outcomes and it is based on the instructor assessment of student performance. This method relies on the instructor's predetermined set of announced standards of performance needed to achieve the course outcomes. Furthermore, a unique method for evaluating achievement of program outcomes has been developed. It provides a systematic mechanism that combines all the results from the various program-level assessment tools to determine an overall rating for the program for each outcome and guidelines for taking corrective action for continuous improvement.
\end{abstract}

\section{Introduction}

In recent years, the Accreditation Board for Engineering and Technology (ABET) introduced a revised set of Engineering Criteria (EC 2000) that are required for accreditation ${ }^{1}$. These criteria are based on assessment of program educational objectives (PEOs) and program outcomes (POs) for continuous improvement (CI). An important part of these requirements is 'to close the loop', i.e. programs are required to use the results of the assessment process to identify and implement changes for program improvement. As a result, most schools have now gone through this new accreditation process and numerous assessment systems, processes and tools have been developed as illustrated by recently reported studies ${ }^{2-8}$, among others. The American Society for Engineering Education (ASEE) provides links to the assessment-related activities of several programs 9 .

To encourage creativity and uniqueness within the engineering education community, ABET EC 2000 criteria provide significant flexibility towards developing an outcomes-based assessment system $^{10,11}$. For example, programs are required to define their own PEOs and demonstrate their achievement through outcomes-based assessment. To contribute to the creativity and uniqueness as demanded by ABET, in the present paper, the assessment system developed at the Charles V. 
Schaefer, Jr. School of Engineering at Stevens Institute of Technology is presented. It includes an innovative technique for direct assessment at the course level. Furthermore, a unique method for evaluating achievement of program outcomes has been developed. It provides a systematic mechanism that combines all the results from the various program-level assessment tools to determine an overall rating for the program for each outcome and guidelines for taking corrective action for continuous improvement.

\section{The Schaefer School of Engineering Assessment System}

The assessment system the Charles V. Schaefer, Jr. School of Engineering was developed based on the processes illustrated in Figure 1. This assessment system generates specific assessment data which are collected and evaluated at the course level by individual faculty, at the program level by the Program Assessment Committee, and finally at the School of Engineering level by the SoE Education and Assessment committee as illustrated in Figure 1. Changes resulting from assessment of outcomes are decided by the Program Assessment Committee, for courses within the program and in concert with the SoE Education and Assessment Committee for engineeringcore courses.

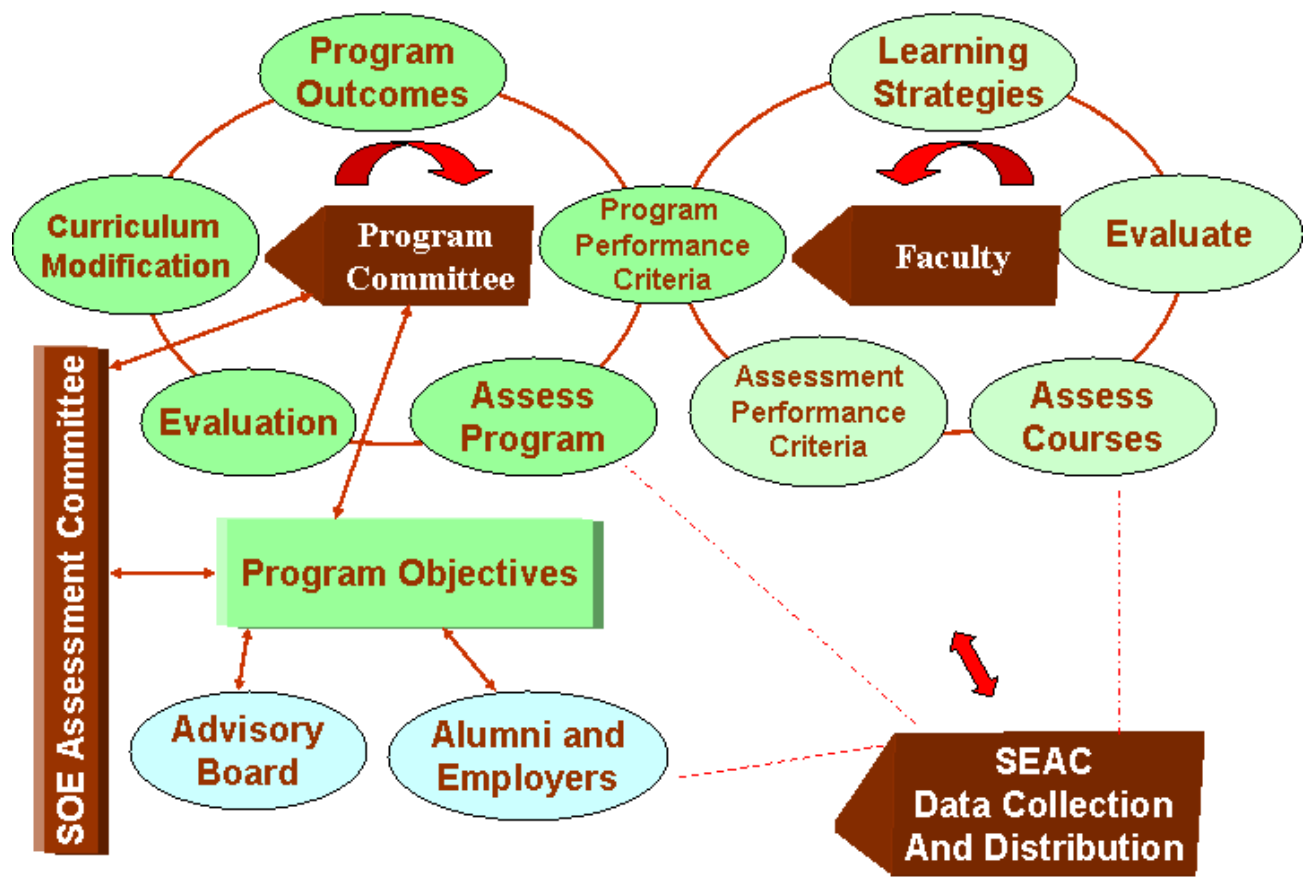

Figure 1: $\quad$ Schaefer School of Engineering Assessment System

The Stevens curriculum is based on a broad core that ensures breadth in the sciences, engineering and the humanities while at the same time allowing for meaningful specialization (depth) in each program $^{12,13}$. On this basis, a three-level hierarchy was developed which spans from the SoE level to the program level to the course level as illustrated in Figure 1. 


\section{Mechanical Engineering Program Objectives}

The educational objectives of the Mechanical Engineering Program are related to the expected accomplishments of graduates few years after graduation. The objectives were developed by the Department faculty, in coordination with and feedback from the School of Engineering Education and Assessment Committee, the External Advisory Board, and the alumni. These objectives address the ABET EC2000 Criterion 2 while directly supporting the mission and objectives of the School of Engineering and the overall mission of the Institute.

The following educational objectives have been established for the Mechanical Engineering Program:

1. Graduates identify and solve problems in mechanical engineering and related fields using their broad-based knowledge of fundamental engineering principles and state-of-the-art tools and techniques (technical breadth).

2. Graduates develop mechanical and thermal devices and systems to meet the needs of society (technical depth).

3. Graduates excel in working within and leading multi-disciplinary teams (professional advancement).

4. Graduates conduct themselves in a socially responsible manner and adapt to technological change (world-view and personal development).

The processes for assessment of program objectives are summarized in Figure 2.

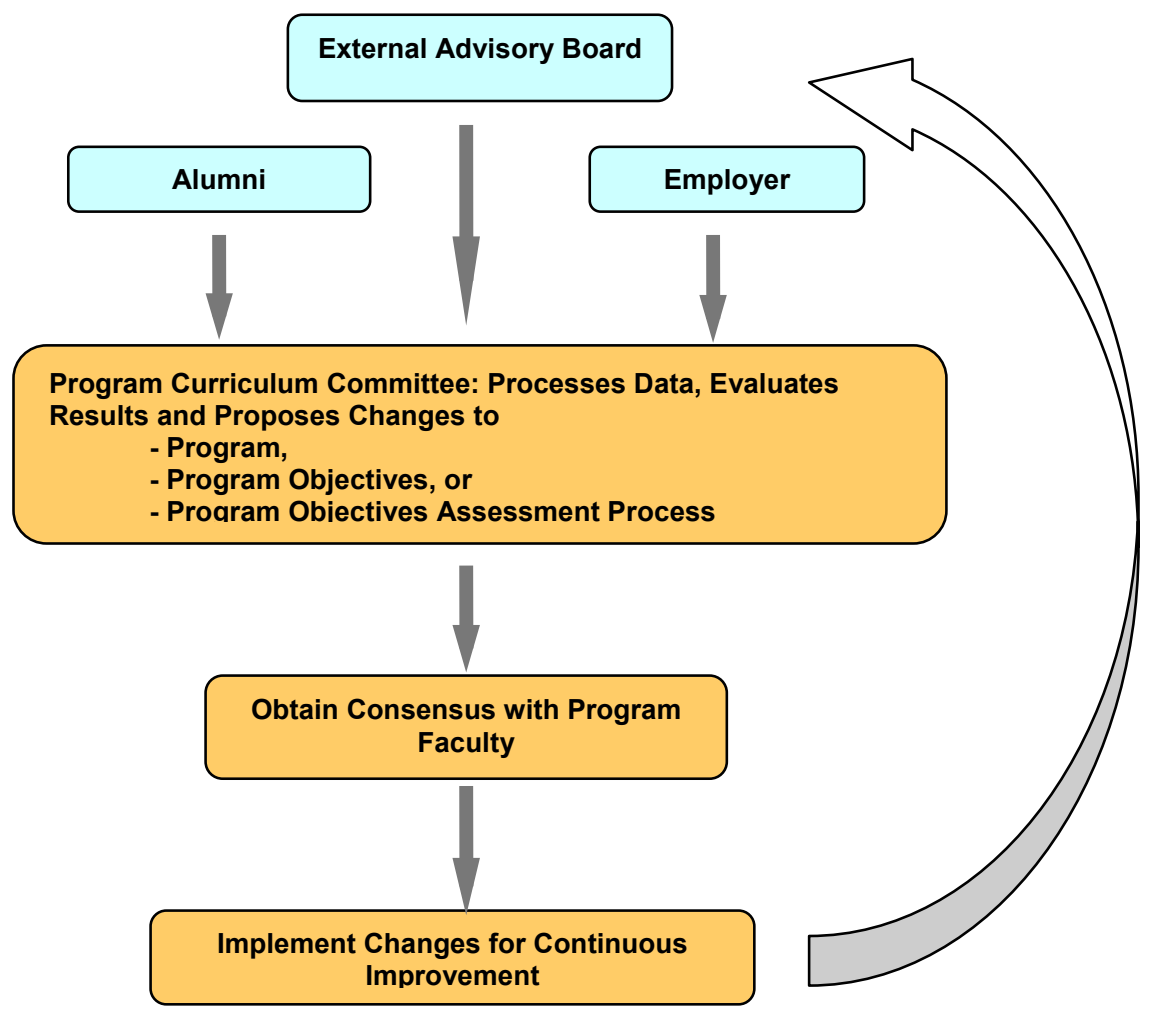

Figure 2: Processes for assessment of Program Objectives (Loop completed every three years)

Proceedings of the 2005 American Society for Engineering Education Annual Conference \& Exposition Copyright (C) 2005, American Society for Engineering Education 


\section{Mechanical Engineering Program Outcomes}

The Mechanical Engineering Program Outcomes are listed in Table 1 which also includes the relationship between the Program Outcomes and ABET Criterion $3(a-k)$. Table 2 illustrates the relationship between Program Objectives and Program Outcomes. The Program Outcomes have been determined based on the following criteria:

- Achievement of the mission and educational objectives of the Mechanical Engineering Program,

- Consistency with the mission, objectives and curriculum outcomes of the School of Engineering, and

- Fulfillment of all of the ABET Criterion $3(a-k)$ and related ABET program criteria.

The Program Outcomes were established by the Program Assessment Committee in consultation with various constituencies and based on feedback from them. Members of constituencies including alumni, External Advisory Board (EAB), current seniors, and employers were involved in the definition and periodic revision of the Program Outcomes. In a feedback cycle, the Program Outcomes have been communicated to various constituencies for their review over time and have evolved into their current form. A set of Program Performance Criteria (PPCs) have been defined for each outcome in a manner that was measurable in order to be able to determine accomplishment of the outcome. 
Table 1: Program Outcomes and their relationship to ABET Criterion 3 (a-k)

\begin{tabular}{|c|c|c|}
\hline \multicolumn{2}{|c|}{$\begin{array}{l}\text { Program Outcomes } \\
\text { By the time of graduation, graduates receiving the Bachelor of Engineering degree } \\
\text { in Mechanical Engineering are expected to have: }\end{array}$} & $\begin{array}{l}\text { ABET } \\
\text { Criterion }\end{array}$ \\
\hline \multicolumn{2}{|c|}{ I. Broad-Based Technical Expertise } & \\
\hline Outcome 1 A\&B & $\begin{array}{l}\text { (Scientific foundations) the ability to use applied scientific knowledge } \\
\text { to solve problems in mechanical engineering and related fields. }\end{array}$ & a \\
\hline Outcome 1C & $\begin{array}{l}\text { (Engineering foundations) the ability to use fundamental engineering } \\
\text { knowledge to solve problems in mechanical engineering and related } \\
\text { fields. }\end{array}$ & $e$ \\
\hline Outcome 2 & $\begin{array}{l}\text { (Experimentation) the ability to design and conduct experiments, and } \\
\text { analyze experimental data for mechanical engineering and related } \\
\text { applications. }\end{array}$ & $b$ \\
\hline Outcome 3 & $\begin{array}{l}\text { (Tools) the ability to use the relevant tools necessary for practice in } \\
\text { mechanical engineering and related fields. }\end{array}$ & $k$ \\
\hline Outcome 4 & $\begin{array}{l}\text { (Technical design) the technical ability to design a mechanical and } \\
\text { thermal engineering device or system. }\end{array}$ & $c$ \\
\hline Outcome 5 & $\begin{array}{l}\text { (Design assessment) the ability to develop and assess alternative } \\
\text { mechanical and thermal system designs based on technical and } \\
\text { non-technical criteria. }\end{array}$ & $c, h$ \\
\hline \multicolumn{2}{|c|}{ II. Professional Advancement and Communications } & \\
\hline Outcome 6 & $\begin{array}{l}\text { (Professionalism) the ability to recognize and achieve high levels of } \\
\text { professionalism in their work. }\end{array}$ & $f$ \\
\hline Outcome 7 & (Leadership) the ability to assume leadership roles. & $d$ \\
\hline Outcome 8 & (Teamwork) the ability to function on teams. & $d$ \\
\hline Outcome 9 & $\begin{array}{l}\text { (Communication) the ability to communicate effectively and } \\
\text { persuasively. }\end{array}$ & $g$ \\
\hline \multicolumn{2}{|c|}{ III. World View and Personal Development } & \\
\hline Outcome 10 & $\begin{array}{l}\text { (Ethics and morals) a critical understanding of ethical and moral } \\
\text { systems in a social context. }\end{array}$ & $f$ \\
\hline Outcome 11 & $\begin{array}{l}\text { (Contemporary Issues) a knowledge of contemporary issues in } \\
\text { Mechanical Engineering and related fields. }\end{array}$ & $j$ \\
\hline Outcome 12 & $\begin{array}{l}\text { (Lifelong learning) a recognition of the need for and an ability to } \\
\text { engage in lifelong learning and development. }\end{array}$ & $i$ \\
\hline Outcome 13 & $\begin{array}{l}\text { (Entrepreneurship) a fundamental knowledge and an appreciation of } \\
\text { the technology and business processes necessary to nurture new } \\
\text { technologies from concept to commercialization. }\end{array}$ & -- \\
\hline
\end{tabular}

Proceedings of the 2005 American Society for Engineering Education Annual Conference \& Exposition Copyright (C) 2005, American Society for Engineering Education 
Table 2: $\quad$ Program Objectives and their relationship to Program Outcomes

\begin{tabular}{|c|c|c|c|c|c|c|c|c|c|c|c|c|c|}
\hline \multirow{2}{*}{$\begin{array}{l}\text { Mechanical Engineering } \\
\text { Program Objective }\end{array}$} & \multicolumn{13}{|c|}{ ME PROGRAM OUTCOME } \\
\hline & 1 & 2 & 3 & 4 & 5 & 6 & 7 & 8 & 9 & 10 & 11 & 12 & 13 \\
\hline $\begin{array}{l}\text { 1. Graduates identify and solve problems in } \\
\text { mechanical engineering and related fields } \\
\text { using their broad-based knowledge of the } \\
\text { fundamental engineering concepts and } \\
\text { state-of-the-art tools and techniques }\end{array}$ & $\checkmark$ & & $\checkmark$ & & & & & & & & & & \\
\hline $\begin{array}{l}\text { 2. Graduates develop mechanical and thermal } \\
\text { devices and systems to meet the needs of } \\
\text { society }\end{array}$ & & $\checkmark$ & & $\checkmark$ & $\checkmark$ & & & & & & & & \\
\hline $\begin{array}{l}\text { 3. Graduates excel in working within multi- } \\
\text { disciplinary teams }\end{array}$ & & & & & & $\checkmark$ & $\checkmark$ & $\checkmark$ & $\checkmark$ & & & & \\
\hline $\begin{array}{l}\text { 4. Graduates conduct themselves in a socially } \\
\text { responsible manner and adapt to } \\
\text { technological change }\end{array}$ & & & & & & & & & & $\checkmark$ & $\checkmark$ & $\checkmark$ & $\checkmark$ \\
\hline
\end{tabular}

As illustrated in Figure 3, the Program Assessment Committee oversees the definition and assessment of Program Outcomes. This Committee is also responsible for collecting and analyzing the data according to an established timeline as discussed below. The Committee report is presented annually at a Department faculty meeting where recommendations are made for program improvement. The Program Committee tracks the changes made and the effectiveness in achieving the revised Program Outcomes.

The Program Outcomes are revised whenever there are changes identified in the Program vision and/or in the needs of constituencies. Moreover, the assessment process described in the following sections provides the opportunity for annual feedback concerning the Program Outcomes. This ensures that Program Outcomes are constantly consistent with the needs of constituencies.

The methods used to assess the program outcomes are based on a common primary set of assessment tools, which are summarized in Table 3. The timeline for data collection and the faculty members or committees responsible for collecting and evaluating assessment data are also presented. The timeline has been developed such that data are collected as efficiently as possible. As part of the continuous improvement process, the timeline and the assessment methods used are reviewed periodically to determine their effectiveness based on the results that each data collection method yields. The faculty has established a set of appropriate metric goals which are used in each assessment tool to measure the level of achievement of Program Outcomes against. 


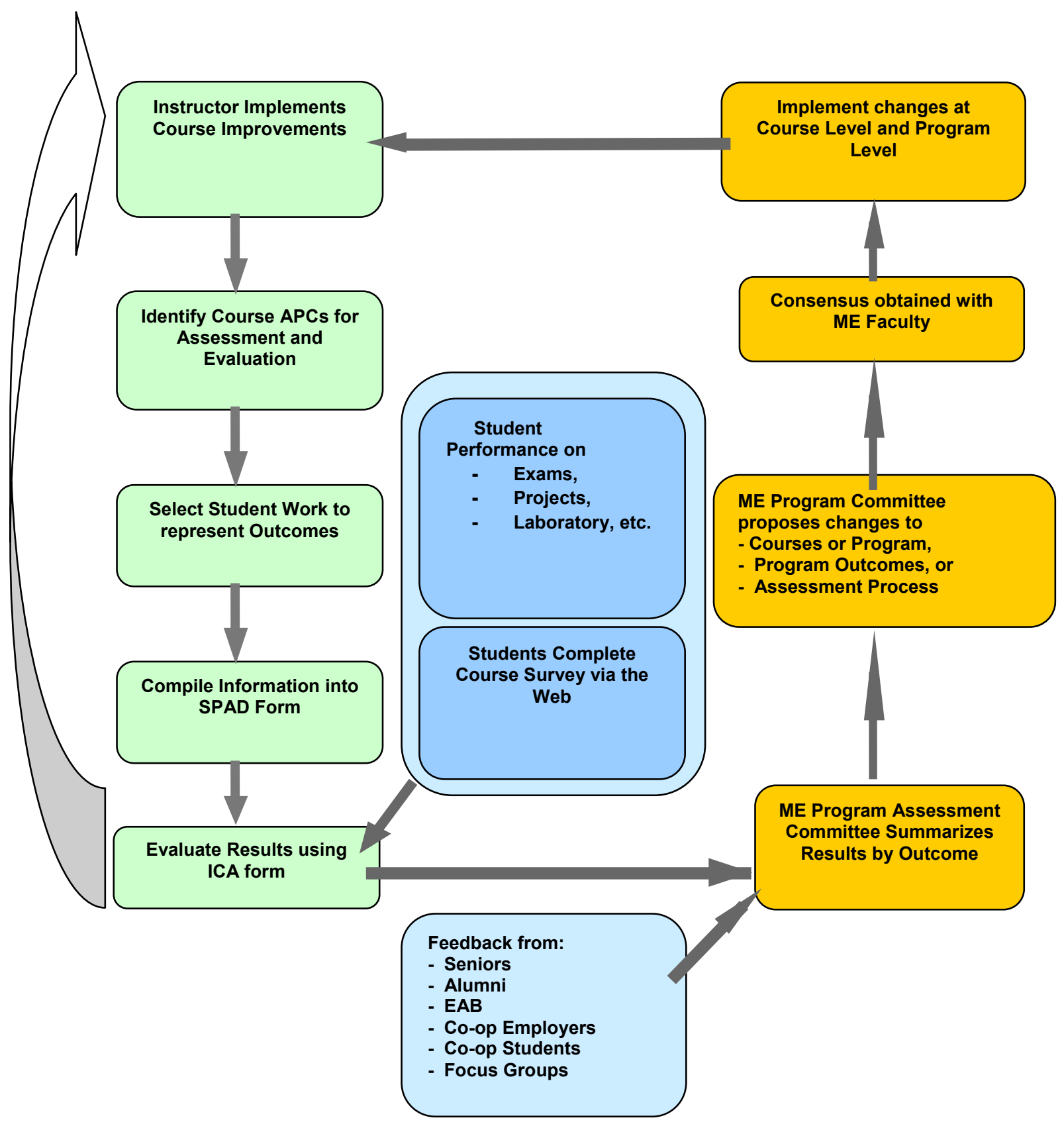

Figure 3: $\quad$ Outcomes Assessment Process (loops performed each year as appropriate)

Proceedings of the 2005 American Society for Engineering Education Annual Conference \& Exposition Copyright (C) 2005, American Society for Engineering Education 
Table 3: Program Outcomes assessment tools and responsibilities

\begin{tabular}{|c|c|c|}
\hline Assessment Tool & Data Collection Deadline & $\begin{array}{l}\text { Responsibility for Data } \\
\text { Collection and Evaluation }\end{array}$ \\
\hline $\begin{array}{l}\text { A. Instructor assessment of } \\
\text { student performance }\end{array}$ & $\begin{array}{l}\text { Upon completion of the final grading } \\
\text { for the course }\end{array}$ & $\begin{array}{l}\text { Individual instructors in } \\
\text { coordination with Program } \\
\text { Assessment Committee }\end{array}$ \\
\hline B. Student survey & Upon completion of the course & $\begin{array}{l}\text { Individual instructors in } \\
\text { coordination with Program } \\
\text { Assessment Committee }\end{array}$ \\
\hline C. Senior exit survey & One month before graduation & $\begin{array}{l}\text { Senior Design Course Instructor } \\
\text { in coordination with Program } \\
\text { Assessment Committee }\end{array}$ \\
\hline D. Alumni survey & $\begin{array}{l}\text { Once a year to Alumni who } \\
\text { graduated from Stevens after one, } \\
\text { three, and five years. }\end{array}$ & Program Assessment Committee \\
\hline $\begin{array}{l}\text { E. External Advisory Board } \\
\text { Feedback }\end{array}$ & $\begin{array}{l}\text { Upon completion of the annual } \\
\text { meeting }\end{array}$ & $\begin{array}{l}\text { Department Director in } \\
\text { coordination with Program } \\
\text { Assessment Committee }\end{array}$ \\
\hline F. Employer evaluations & $\begin{array}{l}\text { Annually to the ten employers who } \\
\text { hire the largest number of graduates. }\end{array}$ & $\begin{array}{l}\text { Program Assessment Committee } \\
\text { (confidential Information) }\end{array}$ \\
\hline $\begin{array}{l}\text { G. Co-op employer } \\
\text { evaluations }\end{array}$ & $\begin{array}{l}\text { At the end of each semester (Fall } \\
\text { and Spring) }\end{array}$ & Program Assessment Committee \\
\hline H. Co-op student survey & $\begin{array}{l}\text { At the end of each semester (Fall } \\
\text { and Spring) }\end{array}$ & $\begin{array}{l}\text { Program Assessment Committee } \\
\text { (confidential information) }\end{array}$ \\
\hline I. Focus Groups & $\begin{array}{l}\text { As needed, based on preliminary } \\
\text { assessment or assessment from the } \\
\text { previous cycle. }\end{array}$ & $\begin{array}{l}\text { Department Director in } \\
\text { coordination with Program } \\
\text { Assessment Committee }\end{array}$ \\
\hline
\end{tabular}

\section{Course-Level Assessment of Outcomes}

As part of continuous assessment and evaluation of the Program Outcomes, the contents of courses in the curriculum are related to the Program Outcomes as described below. A detailed set of Course Outcomes has been developed for each course. These Course Outcomes are then used to determine the effectiveness of the curriculum in achieving the Program Outcomes. A fundamental and direct assessment tool used to demonstrate achievement of Course Outcomes is based on the instructor assessment of student performance. This relies on the instructor's predetermined set of announced standards of performance needed to achieve the course outcomes. It is conducted by each instructor by taking the following steps:

- Development of a list of Course Outcomes (Assessment Performance Criteria, APC) for the course.

- Mapping of the Course Outcomes with the Program Performance Criteria related to Program Outcomes.

Proceedings of the 2005 American Society for Engineering Education Annual Conference \& Exposition Copyright (C) 2005, American Society for Engineering Education 
- Identification of Assessment Instruments. An Assessment Instrument is a piece of student work that can be uniquely identified with an APC. Examples include one or more of the following: (1) an individual quiz or exam question, (2) an individual laboratory assignment, (3) a project assignment, or (4) an individual homework problem

A separate rating of the Assessment Instrument used may or may not be part of the student's grade. For example, a design report may have an overall grade assigned to it, but for the purpose of assessing the student's ability to express technical material in writing, a separate rating will be assigned for writing quality on that piece of work by the instructor.

All ratings are converted to a zero-to-four scale according to the instructor's judgment. They are then analyzed to indicate the distribution of student performance for each course outcome. This information is collected on a Student Performance Assessment Data (SPAD) Form, which displays Assessment Instrument, the number of students in the program being assessed, and measures of a high, low and median rating for the performance of those students on that Assessment Instrument. A sample of a Student Performance Assessment Data (SPAD) Form is illustrated in Table 4.

For each course in the curriculum, a Web-based course survey is conducted. The survey is sent to each student before the end of the semester. The survey includes two sections, one section on the instructor evaluation and the other on Course Outcomes. The collected data provides feedback on the overall effectiveness of the course and program from the students' point of view. As part of the assessment process, useful feedback needed to assess the instructor's performance in the course is also obtained from this survey. The instructor uses this tool to improve the method of teaching and interacting with the students. In each section of the survey, an opportunity for providing comments is also included. The survey inquires of the students about their perception of their quality of learning with respect to the Course Outcomes. Specifically, they are asked to indicate for each course outcome whether they had a "great learning experience," "significant new learning," "some new learning," or "little new learning." At the end of the final exam period of the semester, instructors are provided with the results of the Course Survey. Instructors then perform a qualitative analysis of the results of the Student Performance Assessment, along with the results of Course Surveys and any other pertinent information to determine which Course Outcomes need to be improved and to plan steps towards that improvement. This information is collected on the Instructor Course Assessment Form, which reports the results of the Course Outcomes Assessment. In this form, the instructor is asked to address the following questions:

1. List course changes made this term. Indicate which changes were made as a result of the assessment process. Comment on the success of the changes made this semester.

2. List Course Outcomes that were not achieved to your satisfaction and your reasoning for feeling these outcomes were not achieved. Base your response on the Course Survey, The Assessment Data Form, and your personal judgment, and indicate which of these you used for each comment.

3. List improvements you plan to make to this course.

4. List and comment on changes you would like to see in Course Outcomes.

Proceedings of the 2005 American Society for Engineering Education Annual Conference \& Exposition Copyright (C) 2005, American Society for Engineering Education 
Table 4: $\quad$ Sample of a Student Performance Assessment Data Form

Instructor: Pochiraju Course: ME345 - Modeling and Simulation Section: A Session: Spring 2002

\begin{tabular}{|c|c|c|c|c|}
\hline Low Grade & Average - Std. Dev. & $25^{\text {th }}$ percentile & Minimum & Median \\
\hline Middle Grade & Average & Median & Maximum & \\
\hline High Grade & Average + Std. Dev. & $75^{\text {th }}$ percentile & \\
\hline
\end{tabular}

\begin{tabular}{|c|c|c|c|c|c|c|c|}
\hline \multirow{2}{*}{ CPC } & \multirow{2}{*}{ APC } & \multirow{2}{*}{$\begin{array}{l}\text { ABET } \\
\text { Crit. } 3\end{array}$} & \multirow{2}{*}{$\begin{array}{l}\text { Description of } \\
\text { Student Work }\end{array}$} & \multicolumn{4}{|c|}{ Summary Statistics of Student Grade } \\
\hline & & & & $\mathbf{N}$ & Low & Average & High \\
\hline $1 \mathrm{C} 2$ & $\begin{array}{l}\text { Model a variety of boundary and } \\
\text { initial value problems using FEM } \\
\text { software. }\end{array}$ & e & Case Study 3 & 29 & 2.6 & 3.20 & 3.6 \\
\hline 3B2 & $\begin{array}{l}\text { Perform manufacturability and } \\
\text { performance evaluations based } \\
\text { on numerical solutions }\end{array}$ & k & Lab Exercise 1, 2,4,6 & 34 & 0.7 & 3.47 & 4.0 \\
\hline 3B3 & $\begin{array}{l}\text { Apply system simulations to } \\
\text { evaluate, redesign and optimize } \\
\text { mechanical systems. }\end{array}$ & k & $\begin{array}{c}\text { Course Grade: This course is about } \\
\text { the system modeling and } \\
\text { simulation. }\end{array}$ & 34 & 1.1 & 3.39 & 4.0 \\
\hline $\begin{array}{l}4 \mathrm{~A} 1 \\
4 \mathrm{~A} 4\end{array}$ & $\begin{array}{l}\text { Utilize a CAD software system to } \\
\text { create and manipulate parts and } \\
\text { assemblies. }\end{array}$ & c & Final Project & 34 & 2.13 & 3.69 & 4.0 \\
\hline $5 \mathrm{C} 1$ & $\begin{array}{l}\text { Conversant with several } \\
\text { modeling and simulation } \\
\text { techniques applicable for design } \\
\text { evaluation }\end{array}$ & $\mathrm{h}$ & Case Study 1: Beam Evaluation & 33 & 2.0 & 3.38 & 4.0 \\
\hline $\begin{array}{l}5 \mathrm{C} 2 \\
5 \mathrm{C} 3\end{array}$ & $\begin{array}{l}\text { Delineate system costs into } \\
\text { component, materials, process, } \\
\text { and tools }\end{array}$ & $\mathrm{h}$ & $\begin{array}{c}\text { Case Study } 2 \text { Plastic Part } \\
\text { Integrated Part-Process Analysis }\end{array}$ & 33 & 1.6 & 2.91 & 4.0 \\
\hline
\end{tabular}

Proceedings of the 2005 American Society for Engineering Education Annual Conference \& Exposition Copyright $\mathbb{C}$ 2005, American Society for Engineering Education 


\section{Course Outcomes vis-à-vis Program Outcomes}

A sample mapping of the Course Outcomes to related Program Outcomes is illustrated in Table 5 which shows a partial listing of engineering core and mechanical-engineering program courses. The level of focus or effort on an individual outcome in a particular course is represented by $\mathrm{H}$ (high), M (medium) or L (low). To provide an overview and for quantitative characterization of the attention to various outcomes, each course ranking can be converted into a numerical ranking, taking the following weights: $\mathrm{H}=3, \mathrm{M}=2$ and $\mathrm{L}=1$. On this basis, a numeric equivalent is computed for each course's ranking with respect to individual outcomes. For each outcome, a weighted sum of contributions from the individual courses is calculated; weighting is by course credits. Then for each outcome a percentage contribution to the total of all outcomes can be calculated.

Figure 4 shows the percentage contributions of each of the individual outcomes to the total over all program outcomes both for ABET Criterion 3 (a-k) and for ME Program Outcomes (1) (13). This illustrates the broad, balanced nature of the ME curriculum and its emphasis on knowledge, tools, practice, and design for mechanical and thermal systems.

\section{Program Outcomes Evaluation}

The Program Assessment Committee with the approval of the program faculty has established acceptable levels of achievement of the various outcomes, in order to be in a position to determine where improvement efforts should be focused.

The results of the assessment methods are compiled into a performance measure or index and as mentioned earlier, suitable benchmarks for acceptable achievement of each outcome have been established. All quantitative results are normalized to a 1-5 scale, with 5 representing excellent performance. A scale of measure of the level of achievement of each outcome is then used as illustrated in Figure 5, which allows a comprehensive look at the assessment data to determine whether corrective actions are necessary. 
Table 5: $\quad$ Sample Mapping of Course Outcomes to Program Outcomes

\begin{tabular}{|c|c|c|c|c|c|c|c|c|c|c|c|c|c|c|}
\hline $\begin{array}{l}\text { Program Outcome } \\
\text { (ABET Criterion) }\end{array}$ & $\begin{array}{c}\text { 1A\&B } \\
\text { (a) } \\
\text { Scientif. } \\
\text { Found. }\end{array}$ & $\begin{array}{c}1 \mathrm{1C} \\
\text { (e) } \\
\text { Eng. } \\
\text { Found. }\end{array}$ & $\begin{array}{c}2 \\
\text { (b) } \\
\text { Experi- } \\
\text { mental }\end{array}$ & $\begin{array}{c}3 \\
\text { (k) } \\
\text { Eng. } \\
\text { Tools }\end{array}$ & $\begin{array}{c}4 \\
\text { (c) } \\
\text { Design }\end{array}$ & $\begin{array}{c}5 \\
\text { (h) } \\
\text { Design } \\
\text { Assess- } \\
\text { ment }\end{array}$ & $\begin{array}{c}6 \\
\text { (f) } \\
\text { Prosess- } \\
\text { ionalism }\end{array}$ & $\begin{array}{c}7 \\
\text { (d) } \\
\text { Leader- } \\
\text { ship }\end{array}$ & 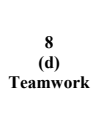 & $\begin{array}{c}9 \\
\mathbf{g} \\
\text { Communic- } \\
\text { ation Skills }\end{array}$ & $\begin{array}{c}10 \\
\text { (f) } \\
\text { Ethics }\end{array}$ & $\begin{array}{c}11 \\
\text { (i) } \\
\text { Contem- } \\
\text { porary } \\
\text { issues }\end{array}$ & $\begin{array}{c}12 \\
\text { (i) } \\
\text { Life-long } \\
\text { Learning }\end{array}$ & $\begin{array}{c}13 \\
\begin{array}{c}\text { Entrepren- } \\
\text { eurship }\end{array}\end{array}$ \\
\hline E121 - Engineering Design I & $\mathrm{L}$ & & & $\mathrm{L}$ & & $\mathrm{L}$ & $\mathrm{M}$ & $\mathrm{L}$ & $\mathrm{M}$ & $\mathrm{L}$ & $\mathrm{L}$ & & & \\
\hline E122 - Engineering Design II & $\mathrm{L}$ & $\mathrm{L}$ & $\mathrm{L}$ & $\mathrm{L}$ & & & M & $\mathrm{L}$ & M & $\mathrm{L}$ & $\mathrm{L}$ & $\mathrm{L}$ & $\mathrm{L}$ & $\mathrm{L}$ \\
\hline E126-Mechanics of Solids & $\mathrm{L}$ & M & & $\mathrm{L}$ & $\mathrm{L}$ & $\mathrm{L}$ & M & $\mathrm{L}$ & M & $\mathrm{L}$ & & & & \\
\hline E231 - Engineering Design III & $\mathrm{L}$ & & $\mathrm{L}$ & $\mathrm{L}$ & $\mathrm{L}$ & $\mathrm{L}$ & M & & M & & & $\mathrm{L}$ & $\mathrm{L}$ & \\
\hline E232 - Engineering Design IV & & & $\mathrm{L}$ & $\mathrm{L}$ & $\mathrm{L}$ & & M & & M & $\mathrm{L}$ & & $\mathrm{L}$ & $\mathrm{L}$ & \\
\hline ME342 - Fluid Mechanics & M & M & M & $\mathrm{L}$ & & & & $\mathrm{L}$ & M & M & $\mathrm{L}$ & & & \\
\hline ME358 - Machine Dynamics \&Mechanisms & M & M & M & $\mathrm{L}$ & $\mathrm{L}$ & $\mathrm{L}$ & & & M & & & & & \\
\hline E321 - Engineering Design V & & & $\mathrm{L}$ & & $\mathrm{L}$ & $\mathrm{L}$ & M & & M & $\mathrm{L}$ & & & & \\
\hline ME322 - Engineering Design VI & & & & M & M & $\mathrm{H}$ & M & & M & $\mathrm{H}$ & & & & $\mathrm{L}$ \\
\hline ME354 - Heat Transfer & M & M & & $\mathrm{L}$ & $\mathrm{L}$ & $\mathrm{L}$ & $\mathrm{L}$ & & & & & & & \\
\hline ME361 - Design of Machine Components & & $\mathrm{H}$ & $\mathrm{L}$ & & $\mathrm{H}$ & $\mathrm{M}$ & & & & & & & & \\
\hline $\begin{array}{l}\text { ME423/424 - Mech. Engineering Design VII } \\
\text { \& VIII }\end{array}$ & & & & M & $\mathrm{H}$ & $\mathrm{H}$ & M & M & $\mathrm{H}$ & M & M & M & & \\
\hline
\end{tabular}
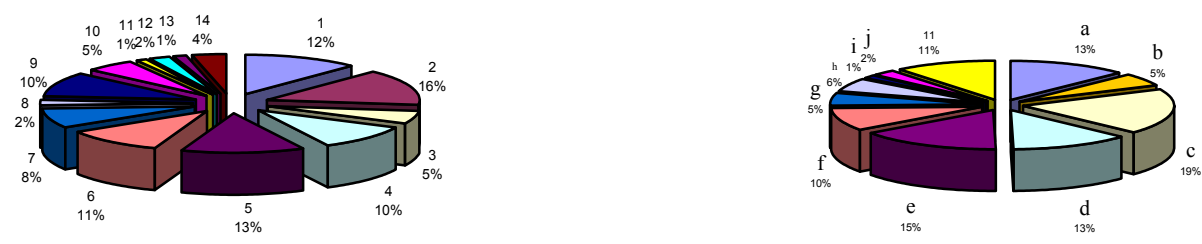

Figure 4: Percentages of coursework classified by: (a) ABET a to $k$ and, (b) ME Program Outcomes

Proceedings of the 2005 American Society for Engineering Education Annual Conference \& Exposition Copyright $(\mathbb{C}$ 2005, American Society for Engineering Education 
Since the quantitative data obtained from various assessment tools are compiled by outcome, the performance of the Mechanical Engineering program is then evaluated by outcome. The Program Assessment Committee set up an interpretation scheme for the data in which an average rating of 3.5 is considered to be satisfactory to mandate only routine changes. However, an outcome rated below 3.5 will trigger a watch list in which actions for improvements are planned and implemented. Such actions are prioritized to a very high importance for those outcomes rated below 3.0.

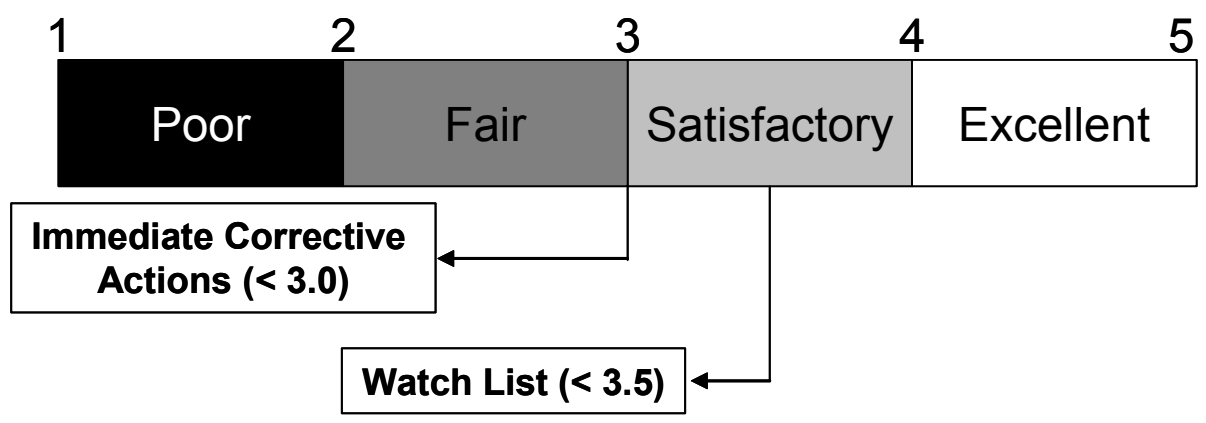

Figure 5: Interpretative scale and positioning of action alarms based on assessment results

It is recognized that it is not possible, using the scheme described above, to demonstrate that every graduate satisfies the condition for satisfactory achievement (rating $>3.5$ ) of every outcome as required by ABET Criterion $3(a-k)$. However, one should bear in mind that assessment methods that are able to show that every graduate meets every ABET Criterion 3 are beyond the current requirements of ABET, and as is revealed through the recent literature, such methods are yet to be developed. The present scheme, as illustrated in Figure 5, is unique as it provides a systematic mechanism that combines all the results from the various assessment tools to determine an overall rating for the program for each outcome and guidelines for taking corrective action for continuous improvement.

As an example of the results obtained for each outcome, a summary of results for Outcome \#3 (Tools) is illustrated in Table 6. 
Table 6. Summary of Results for Outcome 3 (Tools)

\begin{tabular}{|c|c|c|c|c|c|c|c|c|}
\hline \multicolumn{9}{|c|}{ Program Outcome 3 (Tools): } \\
\hline \multirow{2}{*}{\multicolumn{5}{|c|}{$\begin{array}{l}\text { Ability to use the relevant tools necessary for } \\
\text { practice in mechanical engineering and related } \\
\text { fields }\end{array}$}} & \multirow{2}{*}{\multicolumn{2}{|c|}{ Poor }} & Satisfactory & $\begin{array}{r}5^{5} \\
\text { Excellent }\end{array}$ \\
\hline & & & & & & & \multicolumn{2}{|c|}{$\uparrow \mathbf{3 . 8 3}$} \\
\hline $\begin{array}{l}\text { Assessment } \\
\text { Tool } \rightarrow\end{array}$ & Instructor & Student & Senior & Alumni & EAB & $\begin{array}{l}\text { Co-op } \\
\text { Employer }\end{array}$ & $\begin{array}{l}\text { Co-op } \\
\text { Student }\end{array}$ & Average \\
\hline Year & & & & & & & & \\
\hline$\downarrow$ & & & & & & & & \\
\hline 2003 & 4.34 & 3.44 & 2.84 & 3.71 & 3.58 & 4.33 & 4.55 & 3.83 \\
\hline 2002 & 4.19 & 3.48 & 2.41 & - & - & 4.33 & 4.28 & 3.74 \\
\hline
\end{tabular}

Table 7 summarizes the two dimensions of the data collected during the assessment process. The data are organized by outcome. Referred to as the "span" of a particular outcome is the percentage of curriculum content pertaining to that outcome relative to the curriculum content for all such outcomes. The level of achievement (on the 1-5 scale used in the various surveys) shows the average level according to the five separate assessment methods used. As sown in Table 7, these data show well-distributed contributions to overall program outcomes and high levels of achievement. The curriculum effectively encompasses the diverse outcomes sought from the program and the relative emphasis on the scientific foundations, breadth of knowledge, design and teamwork skills that differentiate the Stevens graduate.

Table 7: A comprehensive look at achievement of Outcomes

\begin{tabular}{|c|c|c|c|c|c|c|c|c|c|c|c|c|c|c|}
\hline Outcome & $1 \mathrm{~A}, \mathrm{~B}$ & $1 \mathrm{C}$ & 2 & 3 & 4 & 5 & 6 & 7 & 8 & 9 & 10 & 11 & 12 & 13 \\
\hline Span & 10.7 & 12.8 & 4.5 & 9.1 & 11.2 & 9.3 & 9.2 & 2.6 & 10.3 & 6.7 & 5.0 & 2.6 & 2.8 & 3.1 \\
\hline Level of Achievement & 4.0 & 4.0 & 3.7 & 3.8 & 3.8 & 3.4 & 4.0 & 4.0 & 4.1 & 3.8 & 3.7 & 3.9 & 3.2 & 3.2 \\
\hline
\end{tabular}

\section{Closing the loop for continuous program improvement}

While numerous types of assessment instruments and processes have been developed and discussed in detail in the literature ${ }^{2-7}$, much less attention has been paid to the existing challenge in correlating/combining feedback from the various tools and drawing conclusions leading to corrective action for program improvement ${ }^{8}$.

The Effectiveness of the assessment tools and processes described above and the reliability and validity of assessment data obtained are continuously monitored through the phased implementation of the system. Each assessment tool used is based on data with which the results of other instruments can be compared for confirmation, or to indicate more information is needed. To close the loop, several changes, both at the program level and at the course level, were identified based on the assessment results obtained. As an example, some of the most significant of these changes are summarized in Table 8. It includes an example of a program change related to experimentation which shows the importance of developing the span of each

Proceedings of the 2005 American Society for Engineering Education Annual Conference \& Exposition Copyright (C) 2005, American Society for Engineering Education 
outcome in the curriculum as illustrated in Figure 4 and Table 7. Additional examples of program changes based on assessment results from a combination of various tools are shown.

Table 8: An example of Program changes based on outcomes assessment

\begin{tabular}{|c|c|c|c|}
\hline Semester/Year & Issue & Reason Initiated & Solution \\
\hline Fall 2001 & $\begin{array}{l}\text { Fluid mechanics } \\
\text { laboratory }\end{array}$ & $\begin{array}{l}\text { EAB, Senior Exit Survey, Low } \\
\text { Outcome \#2 span }\end{array}$ & $\begin{array}{l}\text { Expanded space, seven } \\
\text { experiments designed, } \\
\text { new equipment installed. }\end{array}$ \\
\hline Fall 2001 & $\begin{array}{l}\text { Thermodynamics } \\
\text { laboratory }\end{array}$ & $\begin{array}{l}\text { Improve experimentation } \\
\text { thread; increase span for } \\
\text { Outcome \#2 }\end{array}$ & $\begin{array}{l}\text { New equipment and } \\
\text { laboratory experience for } \\
\text { students. }\end{array}$ \\
\hline Fall 2002 & $\begin{array}{l}\text { Mechanical } \\
\text { Systems } \\
\text { Laboratory }\end{array}$ & $\begin{array}{l}\text { Well received lecture/lab format } \\
\text { by students both in course } \\
\text { surveys and performance }\end{array}$ & $\begin{array}{l}\text { Added laboratory } \\
\text { components to ME } 358 \text {, } \\
\text { ME } 361 \text { and ME } 598 .\end{array}$ \\
\hline Spring 2002 & $\begin{array}{l}\text { Remote } \\
\text { Experimentation }\end{array}$ & $\begin{array}{l}\text { Senior Exit Survey: concerns } \\
\text { about laboratory access and } \\
\text { limited experimental setups }\end{array}$ & $\begin{array}{l}\text { NSF funded remote } \\
\text { laboratory for dynamics } \\
\text { systems was implemented } \\
\text { and integrated with the } \\
\text { curriculum }\end{array}$ \\
\hline Fall 2002 & $\begin{array}{l}\text { Robotics } \\
\text { Laboratory }\end{array}$ & $\begin{array}{l}\text { Co-op employer and senior } \\
\text { design sponsor concerns } \\
\text { regarding experience with real } \\
\text { systems }\end{array}$ & $\begin{array}{l}\text { Revised robotics lab. with } \\
\text { new equipment and } \\
\text { modern control modules. }\end{array}$ \\
\hline Fall 2002 & $\begin{array}{l}\text { Capstone senior } \\
\text { design } \\
\text { experience }\end{array}$ & $\begin{array}{l}\text { Senior design course survey } \\
\text { and senior exit survey } \\
\text { comments }\end{array}$ & $\begin{array}{l}\text { Several improvements in } \\
\text { course structure and its } \\
\text { integration with other } \\
\text { program elements like } \\
\text { Design VI and ME } 345\end{array}$ \\
\hline Spring 2002 & Student Lounge & $\begin{array}{l}\text { Senior exit surveys, Enhance } \\
\text { student-faculty interaction and } \\
\text { increase team spirit }\end{array}$ & $\begin{array}{l}\text { A smaller conference room } \\
\text { is expanded into a bright } \\
\text { student lounge space with } \\
\text { new furniture }\end{array}$ \\
\hline Fall 2001-2002 & $\begin{array}{l}\text { Communication } \\
\text { Skills }\end{array}$ & $\begin{array}{l}\text { EAB comments on professional } \\
\text { presentations by students }\end{array}$ & $\begin{array}{l}\text { Increased opportunities for } \\
\text { presentations and use of } \\
\text { multimedia Web-based } \\
\text { dissemination methods. }\end{array}$ \\
\hline
\end{tabular}

An important component of the overall assessment process is monitoring of the program changes that are implemented to determine how well they respond to the reasons for which they were initiated and whether they are achieving the desired purpose.

Multi-year documentation of the various processes, assessment results, as well as the resulting changes made for improvement are vital to provide evidence that the assessment results are applied effectively to the further development and improvement of the program. 
It is anticipated that through continuous monitoring of the entire assessment system as discussed above, new issues will arise, plans will change, and instruments will be modified and improved leading to more effective program assessment.

\section{Conclusions}

The assessment system developed for the Mechanical Engineering Program within the Charles V. Schaefer, Jr. School of Engineering at Stevens Institute of Technology is presented with emphasis on the outcomes assessment strategy developed and samples of the assessment instruments/tools that were designed. Each of the assessment tools have evolved over the past three years and will continue to be revised for better efficiency and improved integration into the departmental routine tasks. In summary, all of the assessment processes appear sustainable, all have been used and developed for more than one assessment cycle, and they are being integrated into the routine tasks within the department while continuous refinements are being made to each process. The Mechanical Engineering Program assessment system at Stevens provides systematic mechanisms that combine all the results from the various assessment tools to generate guidelines for evaluation and taking corrective action for continuous improvement of the program. It is hoped that the assessment system described in this paper contributes to the creativity and uniqueness that ABET requires from each accredited program.

\section{References}

1. Engineering Accreditation Commission, "Criteria for Accrediting Engineering Programs," Accreditation Board for Engineering and Technology, Inc., Baltimore, Maryland, 2002-2003 http://www.abet.org.

2. Leonard, M.S., and Nault, E.W., “An Integrated Approach to Evaluation of Program Educational Objectives and Assessment of Program Outcomes Using ABET Criteria for Accreditation of Engineering Programs" Proceedings of the 2004 ASEE Annual Conference, Session 1657.

3. Karimi, A., Clutter, K., and Arroyo, A., "An Example of Course and Program Outcome Assessment," Proceedings of the 2004 ASEE Annual Conference, Session 1793.

4. Shay, L.A., Goda, B.S., Hanlon, P., and Hill, J.D., Outcome Assessment at the U. S. Military Academy, Proceedings of the 2004 ASEE Annual Conference, Session 2532.

5. Pidaparti, R.M., and Akay, H.U., ME Curriculum Redesign Through an Assessment Process, Proceedings of the 2004 ASEE Annual Conference, Session 3257.

6. Sharma, A.D., Vásquez Espinosa, R.E., "Continuous Improvement Educational Initiative: a Campus-Wide Assessment Effort," Proceedings of the 2004 ASEE Annual Conference, Session 3431.

7. Goodson, C., Faulkenberry, L., Miertschin, S., and Stewart, B., "Comprehensive Program Assessment: The Whys and Wherefores," Proceedings of the 2004 ASEE Annual Conference, Session 3431.

8. Soundarajan, N., Program assessment and program improvement: closing the loop," Assessment \& Evaluation in Higher Education, Vol. 29, No. 5, October 2004. 


\title{
9. http://www.asee.org/colleges
}

10. ABET Faculty Workshop for Continuous Improvement, Version 1.0, June 2002, Montreal, Canada.

\author{
11. ABET Faculty Workshop for Continuous Improvement, Version 2.0, January 2003, \\ Baltimore, MD.
}

12. http://www.soe.stevens-tech.edu/Academics/core.html

13. http://www.stevens.edu/engineering/me/Undergraduate/curriculum.html

\section{BIOGRAPHICAL INFORMATION}

HAMID A. HADIM is an Associate Professor of Mechanical Engineering at Stevens Institute of Technology. In addition to engineering education, his current research interests include multi-disciplinary design and optimization, thermal design and analysis in electronics packaging systems, thermal convection in porous media. $\mathrm{He}$ is the Recipient of the Alexander Humphreys Distinguished Teaching Award in 2003 and the Jess H. Davis Memorial Research Award in 1995 from Stevens.

KISHORE POCHIRAJU is an Associate Professor of Mechanical Engineering and also serves as the Director of the Design and Manufacturing Institute (DMI) at Stevens Institute of Technology. He teaches graduate and undergraduate courses in modeling and simulation of electromechanical systems and his research is in the fields of computational mechanics, integrated part and process development, and durability of composites materials. His publications span the fields of micromechanics and finite element modeling and simulation of multi-disciplinary problems.

COSTAS CHASSAPIS is the Director of the Department of Mechanical Engineering and Professor of Mechanical Engineering at Stevens Institute of Technology. His research interests are in knowledge-based engineering systems; computer-aided design and manufacturing. At Stevens he has developed a number of undergraduate and graduate courses in the design and manufacturing areas.

DAVID A. VACCARI is an Associate Professor of Environmental Engineering at Stevens Institute of Technology, and director of the Stevens Engineering Assessment Center. He has a Bachelors, Masters and Ph.D. in environmental science and a Masters in Chemical Engineering, all from Rutgers University. His research areas of specialization include water pollution control and nonlinear empirical modeling.

KEITH SHEPPARD is a Professor of Materials Engineering and Associate Dean of Engineering at Stevens Institute of Technology. He earned the B.Sc. from the University of Leeds, England and Ph.D. from the University of Birmingham, England, both in Metallurgy. As Associate Dean, Sheppard is primarily responsible for undergraduate programs. He is a previous Chair of the ASEE Design in Engineering Education Division.

GEORGE KORFIATIS is McLean Professor of Environmental and Engineering and Dean of Engineering at Stevens Institute of Technology. He obtained his B.S in Civil Engineering and Ph.D. in Water Resources/Environmental Engineering from Rutgers University. Prior to assuming the Dean's position, he was, Director of the Nichols Center for Environmental Systems. 